\title{
Analisis Kinerja Keuangan Provinsi Jambi
}

\author{
Sudirman ${ }^{1}$, Susilawati ${ }^{2}$ \\ Dosen Fakultas Ekonomi Universitas Batanghari ${ }^{1,2}$
}

\begin{abstract}
The contribution of local revenue (PAD) to regional income during the 2012-2016 period on average was 37.99\% per annum and for 2012 the contribution of local revenue to regional income was $37.02 \%$. This is due to the fact that the receipt of original regional income from third party contributions is very large. On average during the period of 2012-2016 the ability of local tax is relatively low if linked to the Gross Regional Domestic Product. While the power of regional retribution if associated with Gross Regional Domestic Product is also still relatively low, but has increased from year to year. This shows that management management in receiving regional retribution has increased. On average during the 2012-2016 period the realization of local tax revenues reached $103.63 \%$ per year (very effective) from the target of local tax revenue. In addition, the realization of regional retribution revenue reaches $103.20 \%$ per year (very effective) from the target of receiving regional retribution. Whereas the realization of BUMD profit income only reached $131.01 \%$ per year (very effective) from the target of BUMD profit income and the realization of other revenue from legitimate $P A D$ only reached $109.36 \%$ per annum (very effective). On average, the economic growth rate of Jambi Province is $5.18 \%$ per year, it is expected that the increase in local tax revenue elasticity will increase by $8.90 \%$ per year. elasticity of the increase in regional retribution receipts is $12.91 \%$ per year. The dependency ratio of Jambi Province in the period of 2012-2016 was an average of 31.69 percent per year. Jambi province's regional autonomy ratio in the 2012-2016 period is an average of 12 percent per year with instructive conditions means it is very dependent on the central government
\end{abstract}

Keywords, locally-generated revenue

\section{PENDAHULUAN}

Konsekuensi dari pelaksanaan UndangUndang Nomor 32 dan Undang-Undang 33 Tahun 2004 tersebut adalah bahwa daerah harus mampu mengembangkan otonomi daerah secara luas, nyata dan bertanggung jawab dalam rangka pemberdayaan masyarakat, lembaga ekonomi, lembaga politik, lembaga hukum, lembaga keagamaan, lembaga adat dan lembaga swadaya masyarakat serta seluruh potensi masyarakat dalam wadah Negara Kesatuan Republik Indonesia. Di sisi lain, saat ini kemampuan keuangan beberapa Pemerintah Daerah masih sangat tergantung pada penerimaan yang berasal dari Pemerintah Pusat. Oleh karena itu bersamaan dengan semakin sulitnya keuangan negara dan pelaksanaan otonomi daerah itu sendiri, maka kepada setiap daerah dituntut harus dapat membiayai diri melalui sumbersumber keuangan yang dikuasainya. Peranan Pemerintah Daerah dalam menggali dan mengembangkan berbagai potensi daerah sebagai sumber penerimaan daerah akan sangat menentukan keberhasilan pelaksanaan tugas pemerintahan, pembangunan dan pelayanan masyarakat di daerah. Pelaksanaan Undangundang Nomor 32 dan 33 Tahun 2004 sebagai penyempurnaan dari Undang-Undang Nomor 22 dan 25 Tahun 1999 telah menyebabkan terjadi perubahan yang sangat mendasar mengenai pengaturan hubungan Pusat dan Daerah, khususnya dalam bidang administrasi pemerintahan maupun dalam hubungan keuangan antara Pemerintah Pusat dan Daerah, yang dalam banyak literatur disebut pemerintahan dalam bidang pertahanan keamanan, politik luar negeri, fiskal dan moneter, peradilan, agama, dan adminsitrasi pemerintahan yang bersifat strategis. Dengan pembagian kewenangan/fungsi tersebut pelaksanaan pemerintahan di daerah dilaksanakan berdasarkan asas desentralisasi, asas dekonsentrasi dan tugas pembantuan. Implikasi langsung dari kewenangan/fungsi yang diserahkan kepada daerah sesuai Undangundang Nomor 32 Tahun 2004 adalah kebutuhan dana yang cukup besar. Untuk itu, perlu diatur hubungan keuangan antara Pusat dan Daerah yang dimaksudkan untuk membiayai pelaksanaan fungsi yang menjadi kewenangannya.Dengan adanya pelimpahan wewenang kepada pemerintah daerah dengan diikuti perimbangan keuangan antara pusat dan daerah, diharapkan pengelolaan penggunaan 
anggaran sesuai dengan prinsip "money follows function" yang diatur dalam Undang-Undang Nomor 33 Tahun 2004. Tetapi mengingat desentralisasi di bidang administrasi juga berarti transfer personal (Pegawai Negeri Sipil) yang penggajiannya menjadi tanggung jawab daerah, prinsip "money follows function" atau penggunaan anggaran sesuai fungsinya, tidak mungkin berlangsung. Menurut Lewis (2001), hal ini terjadi karena Dana Alokasi Umum (DAU) yang menjadi sumber utama pendapatan daerah pada umumnya sebagian besar akan digunakan untuk membiayai pengeluaran rutin, sehingga anggaran untuk pembangunan menjadi kecil.

Untuk menyelenggarakan otonomi daerah yang luas, nyata dan bertanggung jawab diperlukan kewenangan dan kemampuan menggali sumber keuangan sendiri, yang didukung oleh perimbangan keuangan antara pusat dan daerah. Dalam hal ini, kewenangan keuangan yang melekat pada setiap kewenangan pemerintah yang menjadi kewenangan daerah. Dalam menjamin terselenggaranya otonomi daerah yang semakin mantap, maka diperlukan usaha-usaha untuk meningkatkan kemampuan keuangan sendiri yakni dengan upaya peningkatan penerimaan Pendapatan Asli Daerah (PAD), baik dengan meningkatkan penerimaan sumber PAD yang sudah ada maupun dengan penggalian sumber PAD yang baru sesuai dengan ketentuan yang ada serta memperhatikan kondisi dan potensi ekonomi masyarakat.

Tujuan yang ingin dicapai dalam penelitian ini adalah untuk: 1) Untuk mengetahui potensi indeks daya pajak daerah sebagai akibat pertumbuhan ekonomi; 2) Untuk mengetahui potensi indeks daya retribusi daerah sebagai akibat pertumbuhan ekonomi; 3) Untuk mengetahui tingkat efektifitas pemungutan pajak daerah, retribusi daerah, laba BUMD, dan lainlain PAD yang Syah; 4) Untuk mengetahui tingkat elastisitas perubahan pajak daerah dan retribusi daerah sebagai akibat dari perubahan PDRB.

\section{METODE PENELITIAN \\ Daerah dan Waktu Penelitian}

Penelitian ini dilaksanakan di Provinsi Jambi, dengan harapan bahwa dalam pelaksanaan otonomi daerah mampu meningkatkan Pendapatan Asli Daerahnya dan mengelola keuangan daerahnya dengan cara yang efektif dan efisien. Sedangkan waktu yang digunakan dalam penelitian ini adalah selama 3 (tiga) bulan.

\section{Metode Pengumpulan Data}

Dokumentasi, yaitu pengumpulan data yang diperoleh melalui laporan-laporan atau dokumen-dokumen yang ada dan informasi lainnya yang ada kaitannya dengan penelitian ini, antara lain: Jambi Dalam Angka, Laporan Realisasi PAD.

\section{Jenis dan Sumber Data}

Jenis data yang digunakan dalam penelitian ini adalah berupa data sekunder. Sedangkan data sekunder adalah data-data pendukung yang diperoleh dari pihak eksteren atau sumber lainnya yang ada hubungannya dengan pajak daerah, retribusi daerah, laba badan usaha milik daerah, lain-lain PAD yang syah, serta pengelolaan keuangan daerah yang dilakukan oleh pihak atau instansi terkait di Provinsi Jambi.

Adapun data yang digunakan dalam penelitian ini bersumber dari Dinas Pendapatan Daerah, Dinas Keuangan dan Asset Daerah, dan Badan Pusat Statistik yang ada di Kota Jambi, serta instansi-instansi terkait lainnya yang dapat menunjang penelitian ini.

\section{Metode Analisis}

Adapun metode analisis yang digunakan dalam penelitian ini adalah sebagai berikut:

1. Analisis Kualitatif, yang digunakan untuk menggambarkan dan menjelaskan potensi sumber-sumber pajak daerah, retribusi daerah, laba usaha daerah, dan lain-lain PAD yang syah.

2. Analisis Kuantitatif, digunakan untuk menjelaskan potensi penerimaan jenis-jenis pendapatan asli daerah, yakni sebagai berikut:

1. Tabel Distribusi Frekuensi

Menjelaskan tentang indeks perubahan dan atau kontribusi variabel penelitian.

2. Analisis Daya Pajak dan Retribusi Daerah Daya pajak daerah dan retribusi daerah adalah rasio antara penerimaan pajak atau retribusi dengan kapasitas atau kemampuan bayar pajak/retribusi di suatu daerah. Salah satu indikator yang dapat digunakan untuk mengetahui kemampuan membayar masyarakat adalah Produk Domestik Regional Bruto (PDRB), dengar formula : 


\section{Daya Pajak/Retribusi $=($ penerimaan pajak $/$ retribusi $) \times 100$ persen \\ $P D R B$}

3. Analisis Efektifitas PAD

Efektivitas adalah mengukur hubungan

dengan potensi retribusi itu sendiri, atau antara hasil pungut suatu retribusi dengan formula :

$$
\text { Efektivitas }=\left(\frac{\text { penerimaan pajak } / \text { retribusi }) \times 100 \text { persen }}{\text { Potensi Pajak } / \text { Retribusi }}\right.
$$

4. Analisis Elastisitas Pajak dan Retribusi

Daerah

Analisis elastisitas dimaksudkan untuk

suatu jenis penerimaan jika terjadi mengetahui tingkat kepekaan perubahan perubahan pada jumlah PDRB, yaitu dengan formula :

$$
\text { epdrd }=(\% \text { penerimaan pajak/retribusi }) \times 100 \text { persen }
$$

5. Analisis tingkat kemandirian Daerah

$$
\mathrm{TKD}=\frac{\mathrm{PAD}}{\mathrm{TPT}}
$$

6. Peta kemampuan Keuangan Daerah
Pemetaan kemampuan keuangan Daerah, menggunakan dua indikator yaitu tingkat kemandirian daerah dan tingkat ketergantungan daerah, yang diklasifika- sikan sebagai berikut;

\begin{tabular}{cll}
\hline Uraian & $\mathrm{TKtD}_{\mathrm{i}}>\mathrm{TKtD}$ & $\mathrm{TKtD}_{\mathrm{i}}<\mathrm{TKtD}$ \\
\hline $\mathrm{TKD}_{\mathrm{i}}>\mathrm{TKD}$ & Wilayah mandiri dengan tingkat & Wilayah Mandiri dengan tingkat \\
& Ketergantungan tinggi & ketergantungan rendah \\
$\mathrm{TKD}_{\mathrm{i}}<\mathrm{TKD}$ & Wilayah belum mandiri & Wilayah belum Mandiri dan tingkat \\
& dan tingkat ketergantungan tinggi & Ketergantungan rendah. \\
\hline
\end{tabular}

Keterangan;

$\mathrm{TKD}_{\mathrm{i}}=$ Tingkat kemandirian daerah $\mathrm{i}$

$\mathrm{TKtD}_{\mathrm{i}}=$ Tingkat ketergantungan daerah $\mathrm{i}$

TKD $=$ rata-rata tingkat kemandirian daerah

$\mathrm{TKtD}=$ rata-rata tingkat ketergantungan daerah

7. Tingkat Ketergantungan Daerah

Tingkat ketergantungan daerah diukur

dengan menggunakan rumus:

$$
T K t D=\frac{P T}{T P D}
$$

Keterangan :

TKtD = Tingkat ketergantungan daerah

$\mathrm{PT}=$ Penerimaan transfer

$\mathrm{TPD}=$ Total penerimaan daerah

\section{Rasio Pajak daerah terhadap APBD}

Tabel 1. Rasio Pajak Daerah terhadap APBD Provinsi Jambi Tahun 2012 - 2016

\begin{tabular}{cccc}
\hline Tahun & Pajak Daerah & APBD & $\%$ \\
\hline 2012 & $808.258 .511 .161,00$ & $2.663 .565 .369 .283,42$ & 30,00 \\
2013 & $841.884 .751 .200,00$ & $2.876 .129 .174 .140,25$ & 29,00 \\
2014 & $1.010 .560 .585 .180,50$ & $3.165 .055 .792 .535,44$ & 31,00 \\
2015 & $1.010 .318 .979 .969,00$ & $3.200 .129 .406 .914,79$ & 31,00 \\
2016 & $966.519 .347 .102,57$ & $3.391 .011 .808 .116,95$ & 28,00 \\
& Rata-rata & & 29,80 \\
\hline
\end{tabular}

Sumber: Badan Keuangan Daerah Provinsi Jambi, 2017

HASIL DAN PEMBAHASAN 
Rasio Retribusi Daerah Terhadap APBD

Tabel 2. Rasio Retribusi Daerah terhadap APBD Provinsi Jambi Tahun 2012 - 2016

\begin{tabular}{cccc}
\hline Tahun & Retribusi Daerah & APBD & $\%$ \\
\hline 2012 & $13.402 .905 .831,00$ & $2.663 .565 .369 .283,42$ & 0,50 \\
2013 & $15.363 .758 .638,00$ & $2.876 .129 .174 .140,25$ & 0,53 \\
2014 & $14.587 .180 .553,00$ & $3.165 .055 .792 .535,44$ & 0,46 \\
2015 & $19.300 .781 .734,00$ & $3.200 .129 .406 .914,79$ & 0,60 \\
2016 & $19.321 .610 .356,80$ & $3.391 .011 .808 .116,95$ & 0,57 \\
& Rata-rata & & 0,53 \\
\hline
\end{tabular}

Sumber: Badan Keuangan Daerah Provinsi Jambi, 2017

\section{Rasio PAD terhadap APBD}

Tabel 3. Rasio PAD terhadap APBD Provinsi Jambi Tahun 2012 - 2016

\begin{tabular}{cccc}
\hline Tahun & Pajak Daerah & APBD & $\%$ \\
2012 & $986.128 .843 .066,28$ & $2.663 .565 .369 .283,42$ & 37,02 \\
2013 & $1.060 .640 .978 .633,25$ & $2.876 .129 .174 .140,25$ & 36,88 \\
2014 & $1.281 .239 .472 .808,44$ & $3.165 .055 .792 .535,44$ & 40,88 \\
2015 & 1.242 .809 .864 .499 .97 & $3.200 .129 .406 .914,79$ & 38,84 \\
2016 & $1.232 .784 .078 .662,95$ & $3.391 .011 .808 .116,95$ & 36,35 \\
& Rata-rata & & 37,99 \\
\hline
\end{tabular}

Sumber: Badan Keuangan Daerah Provinsi Jambi, 2017

Tingkat Ketergantungan Daerah Provinsi Jambi

Tabel 4. Rasio tingkat Ketergantungan Daerah Provinsi Jambi Tahun 2012 - 2016

\begin{tabular}{ccccl}
\hline Tahun & Dana Transfer & TPD & $\%$ & \multicolumn{1}{c}{ Keterangan } \\
\hline 2012 & $764.625 .562,00$ & $2.663 .565 .369 .282,4$ & 28,70 & $\begin{array}{l}\text { Ketergantungan Fiskal } \\
\text { /Kinerja Keuangan } \\
\text { cukup Baik } \\
\text { Ketergantungan Fiskal }\end{array}$ \\
2013 & $887.613 .852,00$ & $2.876 .129 .174 .140,3$ & 30,86 & $\begin{array}{l}\text { /Kinerja Keuangan } \\
\text { cukup Baik }\end{array}$ \\
2014 & $997.693 .222,00$ & $3.165 .055 .792 .535,4$ & 31,52 & $\begin{array}{l}\text { Ketergantungan Fiskal } \\
\text { /Kinerja Keuangan } \\
\text { cukup Baik } \\
\text { Ketergantungan Fiskal } \\
\text { /Kinerja Keuangan } \\
\text { cukup Baik } \\
\text { Ketergantungan Fiskal } \\
\text { /Kinerja Keuangan } \\
\text { cukup Baik }\end{array}$ \\
\hline
\end{tabular}

Sumber: Badan Keuangan Daerah Provinsi Jambi, 2017

\section{Kemandirian Daerah Provinsi Jambi}

Tabel 5. Rasio Kemandirian Daerah Provinsi Jambi Tahun 2012 - 2016

\begin{tabular}{ccccc}
\hline Tahun & PAD & Dana Transfer & $\%$ & Keterangan \\
\hline 2012 & $986.128 .843 .066,28$ & 764.625 .562 .000 & 12,89 & Instruktif \\
2013 & 1.060 .640 .978 .633 .25 & 887.613 .852 .000 & 11,95 & Instruktif \\
2014 & 1.281 .239 .472 .808 .44 & 997.693 .222 .000 & 12,84 & Instruktif \\
2015 & 1.242 .809 .864 .499 .79 & 1.067 .110 .634 .000 & 11,64 & Instruktif \\
2016 & 1.232 .784 .078 .662 .29 & 1.152 .097 .330 .000 & 10,70 & Instruktif \\
& Rata rata & & 12,00 & Instruktif \\
\hline
\end{tabular}




\section{Pemetaan Kinerja}

Tabel 6. Pemetaan Kinerja Daerah Provinsi Jambi Tahun 2012 - 2016

\begin{tabular}{lc}
\hline \multicolumn{1}{c}{ Keterangan } & Kuadran \\
\hline PENDAPATAN DAERAH & 2 \\
Pendapatan Asli Daerah & 2 \\
Pajak Daerah & 2 \\
Retribusi Daerah & 3 \\
Hasil Perusahaan Milik Daerah \& Pengelolaan kekayaan daerah yg dipisahkan & 4 \\
Lain-lain PAD yang Sah & 2 \\
Dana Perimbangan & 2 \\
Bagi Hasil Pajak & 4 \\
Bagi Hasil Bukan Pajak/Sumber Daya Alam & 2 \\
Dana Alokasi Umum & 1 \\
Dana Alokasi Khusus & 3 \\
Lain-lain Pendapatan yang Sah & 1 \\
\hline
\end{tabular}

Sumber: data diolah,2017

\section{Klasifikasi}

Tabel 7. Klasifikasi Daerah Provinsi Jambi Tahun 2012 - 2016

\begin{tabular}{cl} 
Kuadran & \multicolumn{1}{c}{ Kondisi } \\
I & Kondisi paling ideal. PAD mengambil peran besar dalam APBD dan daerah punya \\
& kemampuan mengembangkan potensi lokal. Kondisi ini ditunjukan dengan besarnya \\
& nilai share disertai nilai growth yang tinggi. \\
& Kondisi ini belum ideal, tapi daerah punya kemampuan mengembangkan potensi \\
& lokal sehingga PAD berpeluang memiliki peran besar dalam APBD. Sumbangan \\
II & PAD terhadap APBD masih rendah namun pertumbuhan ( $g$ rowth) PAD tinggi \\
& Kondisi ini belum ideal. Peran PAD yang besar dalam APBD punya peluang \\
& mengecil karena pertumbuhan PADnya kecil. Di sini sumbangan PAD terhadap \\
III & APBD tinggi, namun pertumbuhan PAD rendah. \\
& Kondisi ini paling buruk. PAD belum mengambil peran yang besar dalam APBD dan \\
& daerah belum punya kemampuan mengembangkan potensi lokal. Sumbangan PAD \\
IV & terhadap APBD rendah dan pertumbuhan PAD \\
& rendah.
\end{tabular}

\section{Peta Kemampuan Keuangan Daerah}

Tabel 8. Peta Kemampuan Keuangan Daerah Provinsi Jambi Tahun 2012 - 2016

\begin{tabular}{cll}
\hline \multicolumn{1}{c}{ Uraian } & \multicolumn{1}{c}{ TKDi $>$ TKD } & \multicolumn{1}{c}{ TKtD $<$ TKtD } \\
\hline TKDi $>$ TKD & Tahun 2012, 2014 & Tahun 2012, 2013, 2014 \\
& Wilayah mandiri dengan tingkat & Wilayah Mandiri dengan tingkat \\
& Ketergantungan tinggi & ketergantungan rendah \\
$\mathrm{TKD}_{\mathrm{i}}<\mathrm{TKD}$ & Tahun 2013, 2015, 2016 & Tahun 2015, 2016 \\
& Wilayah belum mandiri & Wilayah belum Mandiri dan \\
& Dan tingkat ketergantungan tinggi & tingkat Ketergantungan rendah \\
\hline
\end{tabular}

Sumber: data diolah, 2017

\section{SIMPULAN}

Berdasarkan hasil penelitian ini beberapa temuan pokok, yakni sebagai berikut:

1. Pertumbuhan ekonomi Provinsi Jambi berdasarkan harga konstan selama periode tahun 2012-20116 secara rata-rata 5,18\% per tahun. dengan kontribusi terbesar bersumber dari sektor pertanian, sektor industri pengolahan, sektor perdagangan, hotel dan restoran, dan sektor pertambangan penggalian.
2. Pertumbuhan ekonomi utamanya pada sektor jasa, meliputi: perdagangan, hotel, restoran/rumah makan, pengangkutan, komunikasi, listrik, keuangan, persewaan, jasa keuangan, dan jasa lainnya berpengaruh positif dan signifikan terhadap peningkatan pendapatan asli daerah. Sedangkan pertumbuhan ekonomi dari sektor industri dan pertambangan berpengaruh positif terhadap pendapatan asli daerah Provinsi Jambi. 
3. Kontribusi pendapatan asli daerah (PAD) terhadap pendapatan daerah selama periode tahun 2012-2016 secara rata-rata sebesar 37,99\% per tahun dan untuk tahun 2012 kontribusi pendapatan asli daerah terhadap pendapatan daerah sebesar 37,02 $\%$. Hal ini disebabkan oleh penerimaan pendapatan asli daerah yang bersumber dari sumbangan pihak ketiga sangat besar.

4. Secara rata-rata selama periode tahun 2012-2016 kemampuan/daya pajak daerah relatif rendah jika dihubungkan dengan Produk Domestik Regional Bruto. Sedangkan daya retribusi daerah jika dihubungkan dengan Produk Domestik Regional Bruto juga masih relatif rendah, namun mengalami peningkatan dari tahun ke tahun. Ini menunjukkan bahwa manajemen pengelolaan penerimaan retribusi daerah mengalami peningkatan.

5. Secara rata-rata selama periode tahun 2012-2016 realisasi penerimaan pajak daerah mencapai $103,63 \%$ per tahun (sangat efektif) dari target penerimaan pajak daerah. Bigitu pula realisasi penerimaan retribusi daerah mencapai $103,20 \%$ per tahun (sangat efektif) dari target penerimaan retribusi daerah. Sedangkan realisasi penerimaan laba BUMD hanya mencapai $131,01 \%$ per tahun (sangat efektif) dari target penerimaan laba BUMD dan realisasi penerimaan lain-lain $\mathrm{PAD}$ yang syah hanya mencapai $109,36 \%$ per tahun (sangat efektif).

6. Secara rata-rata tingkat pertumbuhan ekonomi Provinsi Jambi sebesar 5,18 \% per tahun, maka diharapkan elastisitas pertambahan penerimaan pajak daerah meningkat $8,90 \%$ per tahun. elastisitas pertambahan penerimaan retribusi daerah sebesar $12,91 \%$ per tahun.

7. Rasio Tingkat ketergantungan daerah provinsi Jambi dalam kurun waktu 2012 2016 secara rata-rata sebesar 31,69 persen pertahun

8. Rasio kemandirian daerah provinsi Jambi dalam kurun waktu 2012 - 2016 cera ratarata 12 persen pertahun dengan kondisi instruktif berarti sangat tergantung dengan pemerintah pusat

9. Pemetaan kinerja pemerintah daerah provinsi Jambi, pendapatan daerah berada pada kuadran 2, PAD juga berada pada kuadran 2, pajak daerah pada kuadran 2, retribusi daerah pada kuadran 3, pengelolaankekayaan daerah yang dipisahkan pada kuadran 4, bagi hasil pajak pada kuadran 4, dana alokasi umum kuadran 1, dana alokasi khusus kuadran 3, lain-lain pendapatan yang sah kuadran 1 .

10. Peta kemampuan keuangan daerah provinsi Jambi, Tahun 2012, 2014 Wilayah mandiri dengan tingkat Ketergantungan tinggi, tahun 2013, 2014 wilayah mandiri dengan tingkat keterantungan rendah, tahun 2015, 2015 wilayah belum mandiri dan tingkat ketergantungan tinggi

11. Tingkat efektifitas realisasi pendapatan asli daerah provinsi Jambi , secara ratarata selama periode tahun 2012-2016 mencapai 109,36 \% (sangat efektif). Hal ini disebabkan:

12. Kontribusi PAD terhadap APBD provinsi Jambi dalam kurun waktu 2012 - 2016 secara rata-rata pertahun 37,91 persen

13. Kontribusi Pajak Kendaraan Bermotor (PKB) terhadap PAD di Provinsi Jambi dalam kurun waktu 2012 - 2016 secara rata-rata 26,87 persen pertahun.

14. Kontribusi Balik Nama Kendaraan Bermotor (BBN-KB) terhadap PAD di Provinsi Jambi dalam kurun waktu 2012 2016 secara rata-rata 25,64 persen pertahun

15. Kontribusi Pajak Bahan Bakar Kendaraan Bermotor (PBB-KB) terhadap PAD di Provinsi Jambi dalam kurun waktu 2012 2016 secara rata-rata 21,51 persen pertahun

16. Kontribusi Pajak Air Permukaan (PAP) terhadap PAD di Provinsi Jambi dalam kurun waktu 2012 - 2016 secara rata-rata 0,01 persen pertahun

17. Kontribusi Pajak Rokok terhadap PAD di Provinsi Jambi dalam kurun waktu 2012 2016 secara rata-rata 0,32 , persen pertahun

18. Kontribusi pemakaian kekayaan daerah terhadap PAD di Provinsi Jambi dalam kurun waktu 2012 - 2016 secara rata-rata 0,60 persen pertahun

19. Kontribusi bagian laba bank Jambi terhadap PAD di Provinsi Jambi dalam kurun waktu 2012 - 2016 secara rata-rata 1,98 persen pertahun

20. Kontribusi penerimaan jasa giro terhadap PAD di Provinsi Jambi dalam kurun 
waktu 2012 - 2016 secara rata-rata 0,25 persen pertahun

21. Kontribusi rekening deposito pada kas daerah terhadap PAD di Provinsi Jambi dalam kurun waktu 2012 - 2016 secara rata-rata 1,93 persen pertahun

22. Kontribusi denda keterlambatan kegiatan terhadap PAD di Provinsi Jambi dalam kurun waktu 2012 - 2016 secara rata-rata 0,93 persen pertahun

23. Kontribusi BLUD RSU Raden Mattaher terhadap PAD di Provinsi Jambi dalam kurun waktu 2012 - 2016 secara rata-rata 2,59 persen pertahun

24. Kontribusi BLUD RSJ terhadap PAD di Provinsi Jambi dalam kurun waktu 2012 2016 secara rata-rata 0,01 persen pertahun

25. Kontribusi penerimaan UPTD AKFAR dan AAK terhadap PAD di Provinsi Jambi dalam kurun waktu 2012 - 2016 secara rata-rata 0,32 persen pertahun

26. Daya pajak daerah selama kurun waktu 2012 - 2016 rata-rata pertahun sebesar 0,64 persen pertahun

27. Daya retribusi daerah selama kurun waktu 2012 - 2016 rata-rata pertahun sebesar 0,11 persen pertahun

28. Rata-rata efektifitas pajak daerah provinsi jambi dalam kurun waktu tahun 2012 2016 adalah 103,63 persen sangat efektif

29. Rata-rata efektivitas retribusi daerah selama kurun waktu 2012 - 2016 sebesar 103, 20 sangat efektif.

30. Perkembangan efektifitas laba BUMD rata-rata 131,01 persen pertahun sangat efektif

31. Penerimaan lain-lain PAD yang sah ratarata pertahun selama kurun waktu 2012 2016 153,62 persen sangat efektif.

32. Elastisitas pajak pada tahun 2013 sebesar 0,03 persen, pada tahun 2014 sebesar 1,74 persen ini menunjukan perubahan PDRB pekah terhadap perobahan pajak. Namun pada tahun 2015 - 2016 perobahan nilai PDRB tidak pekah terhadap perobahan pajak.

33. Elastisitas retribusi daerah pada tahun 2013 sebesar 1,13 persen ini menunjukkan kepekahan perobahan nilai PDRB terhadap perobahan nilai pajak, pada tahun 2015 kepekahan PDRB terhadap nilai pajak sebesar 45,50 perse.

\section{DAFTAR PUSTAKA}

Anonim, 1999, Undang-Undang Otonomi Daerah 1999, Sinar Grafika,

Jakarta.

Anonim, 2009, Undang-Undang Nomor 28 Tahun 2009 Tentang Pajak Daerah dan Retribusi Daerah, Sinar Grafika, Jakarta

Anonim, 2004, Undang-undang No.23 Tahun 2004 tentang perimbangan keuangan antara pemerintah pusat dan pemerintah daerah

Anonim, 2009, Undang- undang No 28 tahun 2009 pajak daerah, yang selanjutnya adalah kontribusi wajib kepada daerah yang tertuang oleh orang pribadi atau badan yang sifatnya memaksa

Aronson, J.R., and Schwartz, E., 1996. Management Policies in Local Government Finance., The International City Management Association. Washington D.C

Badan Pusat Statistik, 2012, Provinsi Jambi Dalam Angka Tahun 2012, Penerbit: BPS Provinsi Jambi

Badan Pusat Statistik, 2013, Provinsi Jambi Dalam Angka Tahun 2013, Penerbit: BPS Provinsi Jambi

Badan Pusat Statistik, 2014, Provinsi Jambi Dalam Angka Tahun 2014, Penerbit: BPS Provinsi Jambi

Badan Pusat Statistik, 2015, Provinsi Jambi Dalam Angka Tahun 2015, Penerbit: BPS Provinsi Jambi

Badan Pusat Statistik, 2016, Provinsi Jambi Dalam Angka Tahun 2016, Penerbit: BPS Provinsi Jambi

Bagian Hukum Setda Provinsi Jambi, Himpunan Peraturan Daerah Provinsi Jambi Tentang Pajak Daerah, Buku I.

Bagian Hukum Setda Provinsi Jambi, Himpunan Peraturan Daerah Tentang Retribusi Daerah, Buku I.

Bagian Hukum Setda Provinsi Jambi, Himpunan Peraturan Daerah Provinsi Jambi Tentang Retribusi Daerah, Buku II. 